\author{
B. Sinsoysal ${ }^{1, *}$, M. Rasulov ${ }^{2}$, O. Yener ${ }^{3}$ \\ ${ }^{1}$ Dogus University, Istanbul, Turkey; \\ ${ }^{2}$ Institute of Oil and Gas, Azerbaijan National Academy of Sciences, Baku, Azerbaijan; \\ ${ }^{3}$ Beykent University, Istanbul, Turkey \\ (E-mail: bsinsoysal@dogus.edu.tr,mresulov@gmail.com,yeneroyku@gmail.com)
}

\title{
Grid method for solution of 2D Riemann type problem with two discontinuities having an initial condition
}

\begin{abstract}
This study aims to obtain the numerical solution of the Cauchy problem for 2D conservation law equation with one arbitrary discontinuity having an initial profile. For this aim, a special auxiliary problem allowing to construct a sensitive method is developed in order to get a weak solution of the main problem. Proposed auxiliary problem also permits us to find entropy condition which guarantees uniqueness of the solution for the auxiliary problem. To compare the numerical solution with the exact solution theoretical structure of the problem under consideration is examined, and then the interplay of shock and rarefaction waves is investigated.
\end{abstract}

Keywords: 2D nonlinear scalar conservation law, Riemann problem, finite differences scheme in a class of discontinuous functions.

\section{Introduction}

In the half plane $R_{+}^{3}=R^{2} \times[0, T)$ we consider the following problem for the function $u=u(x, y, t)$

$$
\begin{gathered}
\frac{\partial u}{\partial t}+\frac{\partial f_{1}(u)}{\partial x}+\frac{\partial f_{2}(u)}{\partial y}=0, \\
u(r \cos \varphi, r \sin \varphi, 0)=u_{0}(\varphi) \equiv\left\{\begin{array}{cc}
u_{1}, & \varphi_{1}<\varphi<\varphi_{2}, \\
u_{2}, & \varphi \in[0,2 \pi] \backslash\left[\varphi_{1}, \varphi_{2}\right] .
\end{array}\right.
\end{gathered}
$$

Here $u_{1}$ and $u_{2}$ are known constants. The existence and uniqueness of the global weak solution verifying the entropy condition of problem (1), (2) is proved in [1-4]. But the methods in these articles do not give enough information about the qualitative nature of the solution. A similar one-dimensional problem has been examined in detail in [5-8].

Obtaining exact solutions of the problems in terms of $(1),(2)$ for the cases $f_{1}(u)=\frac{u^{2}}{2}$ and $f_{2}(u)=\frac{u^{3}}{3}$ was first discussed in [9]. This technique is referred to as Guckenheimer structure in the literature. In [10-18] Guckenheimer structure is developed under conditions

$$
f_{1}(u), \quad f_{2}(u) \in C^{3}\left(R_{1}\right), \quad f_{1}^{\prime \prime}(u)>0, f_{2}^{\prime \prime}(u)>0,\left(\frac{f_{1}^{\prime \prime}(u)}{f_{2}^{\prime \prime}(u)}\right)^{\prime}>0
$$

and generalized characteristic analysis method has been suggested. In [19-23] various numerical methods have been developed for problem (1), (2).

In [22-25] a new method is proposed in a class of discontinuous functions to obtain the exact solution of problem (1), (2) in which $f_{1}(u)=\frac{u^{2}}{2}$ and $f_{2}(u)=\frac{u^{2}}{2}$ have both continuous initial functions with compact support and two-piece constant initial function. The same method is also included in [26] for the Cauchy problem for the one-dimensional Hopf equation.

\footnotetext{
${ }^{*}$ Corresponding author.

E-mail: bsinsoysal@dogus.edu.tr
} 
In this paper for problem (1), (2) we introduce a special auxiliary problem with some advantages over the main problem. Using the proposed auxiliary problem, a new finite difference method is developed to find the numerical solution of the main problem. To compare the resulting solution with exact solution, and for sake of simplicity, we first consider the exact solution of the problem with $f_{1}(u)=\frac{u^{2}}{2}$ and $f_{2}(u)=\frac{u^{2}}{2}$. Proposed method is also valid for other $f_{1}(u)$ and $f_{2}(u)$ functions satisfying condition (3).

As is well known, equation (1) is invariant to the transformation $(x, y, t) \rightarrow(c x, c y, c t)$ for any $c>0$, and due to the existence and uniqueness theorem the problem has a self-similar solution as follows

$$
u(x, y, t)=u\left(\frac{x}{t}, \frac{y}{t}, 1\right), \quad t>0 .
$$

For this reason, equation (1) will be considered in the domain $\left(\xi=\frac{x}{t}, \eta=\frac{y}{t}\right)$. Under the coordinates $(\xi, \eta)$ equation (1) can be written as follows for a continuously differentiable $u$

$$
(\xi-u) u_{\xi}+(\eta-u) u_{\eta}=0
$$

The initial condition for (4) becomes

$$
\begin{aligned}
& \lim _{\tan \varphi=\frac{\eta}{\xi},} u(\xi, \eta)=u_{0}(\varphi), \quad \varphi \in[0,2 \pi] . \\
& \xi^{2}+\eta^{2} \rightarrow \infty
\end{aligned}
$$

So, outside a sufficient distance on $(\xi, \eta)$ domain, the discontinuities of $u_{0}(\varphi)$ function produces two types of simple waves; shock waves and rarefaction waves (including semi-contact discontinuity). The importance of Riemann solution is the examination of the interaction of these waves in the region that includes the coordinate origin.

Since equation (4) is a first order differentiable equation, the following is equivalent to an ordinary differentiable system of equations

$$
\left\{\begin{array}{c}
\frac{d \eta}{d \xi}=\frac{\xi-u}{\eta-u} \\
\frac{d u(\xi, \eta(\xi))}{d \xi}=0
\end{array}\right.
$$

Thus, the function $u$ takes constant values over the following characteristics

$$
\frac{d \eta}{d \xi}=\frac{\xi-u}{\eta-u} .
$$

It is clear that the characteristics are the following lines for any $k$

$$
\eta=u+k(\xi-u)
$$

As it is seen, the characteristic lines are the lines that end at the singular points $(\xi, \eta)=(u, u)$ of the integral curve of (5). These singular points match the characteristic lines defined as follows after the transformation of $u$

$$
\left\{\begin{array}{l}
x=u t, \\
y=u t .
\end{array}\right.
$$

Thus, the singular curve of the characteristics becomes $\Gamma(u):\{\eta=\xi\}$. The singular curves of the singularities, similar to the singular curve of characteristics, are the same as $\Gamma(u), \Gamma_{S}(u, \bar{u}) \subseteq\left\{(\xi, \eta) \in R^{2}, \quad \eta=\xi\right\}$, since each of the lines originating from the origin of singularity of Riemann data are the edges of the characteristic domain.

When $u_{1}=1, u_{2}=-1$, two noninteracting rarefaction waves originating from $\{x>0, y=0\}$ and $\{x=0, y>0\}$ occur sufficiently outside of the region that includes the coordinate origin. The solution at $t=1$ becomes as follows [19]

$$
u(x, y, 1)=v(\xi, \eta)=\left\{\begin{array}{c}
1, \quad \xi>1 \text { and } \eta>1 \\
-1, \quad \xi<-1 \text { or } \eta<-1 \\
\eta, \quad \xi>\eta \text { and }-1<\eta<1 \\
\xi, \quad \xi<\eta \text { and }-1<\xi<1
\end{array}\right.
$$

as shown in Figure 1a. 

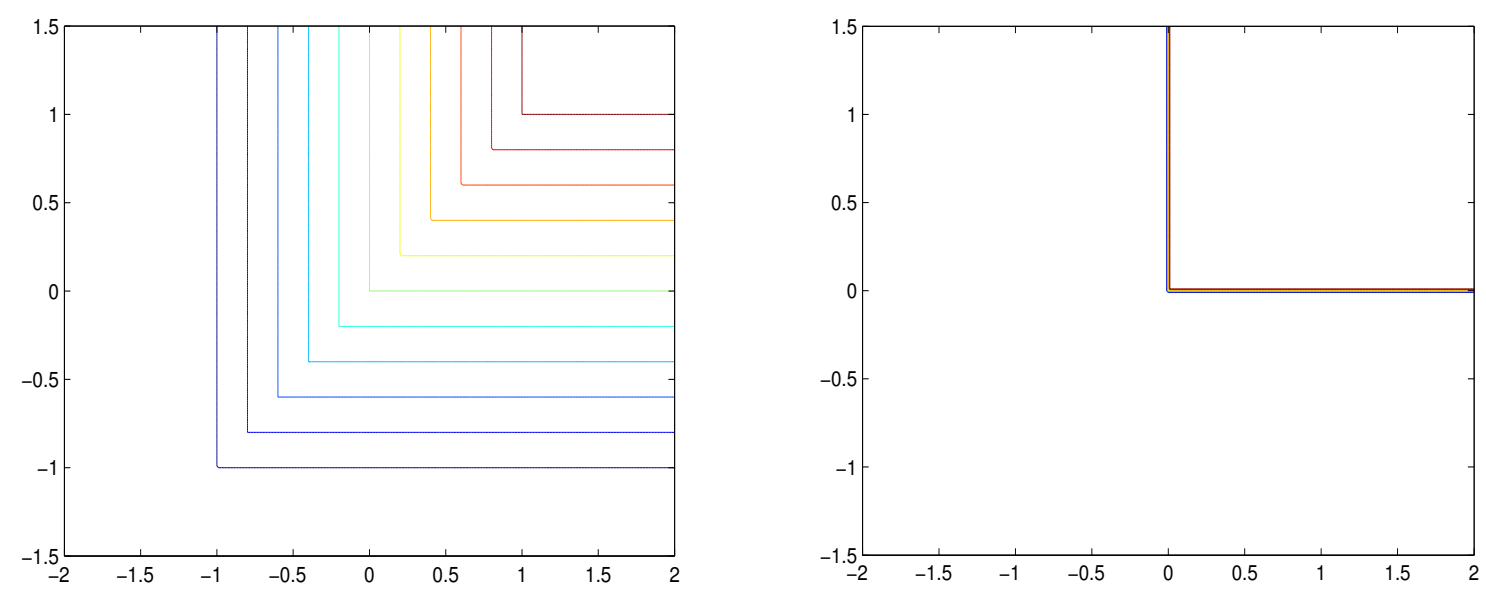

Figure 1. a) The exact solution to (1), (2) when $u_{1}=1, u_{2}=-1, t=1$.

b) The exact solution to (1), (2) problem, $u_{1}=-1, \quad u_{2}=1, t=1$, [19].

Since these waves do not interact, we can expand them to $(\xi, \eta)$ domain.

When $u_{1}=-1, u_{2}=1$ in the solution of problem (1), (2) two shock waves occur along the lines $\{x>0, y=0\}$ and $\{x=0, y>0\}$ sufficiently outside the region that include the origin. We can expand these waves without interaction until the coordinate origin, preserving the entropy condition and reach the solution as follows

$$
u(\xi, \eta)=\left\{\begin{aligned}
&-1, \quad \xi>0, \quad \eta>0 \\
& 1, \text { otherwise }
\end{aligned}\right.
$$

as seen in Figure 1b.

\section{Auxiliary problem and numerical solution}

To find the numerical solutions to the aforementioned problems various finite difference methods have been investigated in the literature $[1,9,21]$. As it is known, the solution to the one dimensional Riemann problem, even when the initial function is sufficiently smooth, contains discontinuities whose locations are unknown beforehand. In two-dimensional problems the number of discontinuities may be infinite. Special investigation is required to see which of these discontinuities are physically meaningful. Thus, directly using finite differencing for the problems which have discontinuities in the solution may spread the discontinuities to several points.

Due to the difficulties of working with the discontinuous functions, the paper proposes an original method to find the numerical solution of the problem that expresses the physical properties of the problem correctly. To this end, no problem arise in using the familiar methods in the literature to find the numerical solution to the auxiliary problem, which has advantages over the original problem but also is conventionally equivalent to the original problem. By using the numerical solution to the auxiliary problem one can find the numerical solution to the original problem.

As mentioned before, a classical solution may not exist for problem (1), (2). In this case, we define a weak solution as follows.

Definition 1. A function $u(x, y, t)$ satisfying initial condition (2) is called as a weak solution of the problem (1), (2), if the following integral relation

$$
\begin{gathered}
\int_{R^{2} \times R^{+}}\left\{u(x, y, t) \frac{\partial f(x, y, t)}{\partial t}+\frac{u^{2}(x, y, t)}{2}\left(\frac{\partial f(x, y, t)}{\partial x}+\frac{\partial f(x, y, t)}{\partial y}\right)\right\} d x d y d t \\
+\int_{R^{2}} f(x, y, 0) u(x, y, 0) d x d y=0
\end{gathered}
$$

holds for any test function $\varphi: R^{2} \times R^{+} \rightarrow R, f(x, y, t) \in \check{C}^{\infty}$.

To obtain the weak solution following [22], if we integrate equation (1) for any $a$ and $c$ over

$$
D_{x y}=\{a<\xi<x, c<\eta<y\} \subset R^{2},
$$


we find the following

$$
\begin{gathered}
\frac{\partial}{\partial t} \int_{a}^{x} \int_{c}^{y} u(\xi, \eta, t) d \xi d \eta+\frac{1}{2}\left(\int_{c}^{y} u^{2}(x, \eta, t) d \eta+\int_{a}^{x} u^{2}(\xi, y, t) d \xi\right) \\
=\frac{1}{2}\left(\int_{c}^{y} u^{2}(a, \eta, t) d \eta+\int_{a}^{x} u^{2}(\xi, c, t) d \xi\right) .
\end{gathered}
$$

Here $a$ and $c$ may also be $\mp \infty$. Let us include the following function

$$
w(x, y, t)=\int_{a}^{x} \int_{c}^{y} u(\xi, \eta, t) d \xi d \eta
$$

We can show

$$
M w(x, y, t)=u(x, y, t)
$$

Here $M(\cdot)=\frac{\partial^{2}(\cdot)}{\partial x \partial y}$ is a differential operator. In the notation of $(7)$ and (8) we can write equation $(6)$ as follows

$$
\frac{\partial w(x, y, t)}{\partial t}+\frac{1}{2} \int_{a}^{y}\left(u^{2}(x, \eta, t)-u^{2}(a, \eta, t)\right) d \eta+\frac{1}{2} \int_{c}^{x}\left(u^{2}(\xi, y, t)-u^{2}(\xi, c, t)\right) d \xi=0
$$

For equation (9) the initial condition will be

$$
w(x, y, 0)=w_{0}(x, y) .
$$

Here $w_{0}(x, y)$ is defined as any continuous and differentiable solution of the following equation

$$
M w_{0}(x, y)=u_{0}(x, y)
$$

We will call problem (9), (10) auxiliary problem.

The auxiliary problem has the following advantages:

1 The differentiability property of the function $w(x, y, t)$ the solution to equation (9) is better than the function $u(x, y, t)$.

2 To find $u(x, y, t)$ its derivative with respect to any variable is not used, as aforementioned derivatives do not even exist.

From (6) we get

$$
\begin{aligned}
& v(x, y, t)=-\frac{1}{2} \int_{0}^{t}\left[\int_{c}^{y} u^{2}(x, \eta, t) d \eta-\int_{c}^{a} u^{2}(a, \eta, t) d \eta\right. \\
&\left.+\int_{a}^{x} u^{2}(\xi, y, t) d \xi-\int_{a}^{x} u^{2}(\xi, c, t) d \xi\right] d \tau
\end{aligned}
$$

Now, for any positive numbers $a_{1}$ and $b_{1}$ we consider the sum

$$
\begin{gathered}
\frac{v(x, y, t)-v\left(x-a_{1}, y, t\right)}{a_{1}}+\frac{v(x, y, t)-v\left(x, y-b_{1}, t\right)}{b_{1}} \\
=\frac{1}{a_{1}}\left\{\int_{0}^{t}\left[\int_{c}^{y} u^{2}\left(\xi-a_{1}, \eta, t\right) d \eta-\int_{a}^{x-a_{1}} u^{2}(\xi, y, t) d \xi\right] d \tau\right. \\
\left.+\int_{0}^{t}\left[\int_{c}^{y} u^{2}(x, \eta, t) d \eta-\int_{a}^{x} u^{2}(\xi, y, t) d \xi\right] d \tau\right\} \\
+\frac{1}{b_{1}}\left\{\int_{0}^{t}\left[\int_{c}^{y-b_{1}} u^{2}(x, \eta, t) d \eta-\int_{a}^{x} u^{2}\left(\xi, \eta-b_{1}, t\right) d \eta\right] d \tau\right. \\
\left.-\int_{0}^{t}\left[\int_{c}^{y} u^{2}(x, \eta, t) d \eta-\int_{c}^{x} u^{2}(\xi, y, t) d \xi\right] d \tau\right\} .
\end{gathered}
$$


According to the consideration (3), we can obtain the following estimate

$$
\begin{gathered}
\frac{v(x, y, t)-v\left(x-a_{1}, y, t\right)}{a_{1}}+\frac{v(x, y, t)-v\left(x, y-b_{1}, t\right)}{b_{1}} \\
\leq \frac{1}{t}\left[\frac{2 M(d-c) T+2 M(b-a) T}{a_{1}}\right]+\frac{1}{t}\left[\frac{2 M T(d-c)+2 M T(b-a)}{b_{1}}\right] \\
=\frac{1}{t}\left[2 M T \frac{(d-c)}{a_{1}}+2 M T \frac{(b-a)}{b_{1}}\right]+\frac{1}{t}\left[2 M T\left(\frac{(d-c)}{a_{1}}+\frac{(b-a)}{b_{1}}\right)\right]=\frac{E}{t},
\end{gathered}
$$

where $E$ is a constant. Condition (11) is called entropy condition. This condition implies that, if we get fixed $t>0$ and let $x$ and $y$ tend to $-\infty$ and $\infty$, respectively, then we can get only jump down in both direction across one discontinuity.

Now we will describe the finite difference algorithm to find the numerical solution of problem (9), (10). To this end we build a grid on $D_{x y}$ region as follows.

Assuming $L$ is a sufficiently big positive integer, we cover $D_{(-L, L)}$ region with $x=x_{i}, y=y_{j}$ lines and build a grid

$$
\Omega_{\left(h_{x}, h_{y}\right)}^{(-\ell, \ell)}=\left\{\left(x_{i}, y_{j}\right): x_{i}=-\ell+i h_{x}, y_{j}=-\ell+j h_{y}, i=0,1,2, \ldots, n, j=0,1,2, \ldots, m\right\} .
$$

Now, let us divide $\left[x_{i}, x_{i+1}\right]$ and $\left[y_{j}, y_{j+1}\right]$ into $p$ and $q$ pieces, respectively. Then, let us define the grid formed by these points as

$$
\Omega_{\left(h_{\xi}, h_{\eta}\right)}^{\left(x_{i}, y_{j}\right)}=\left\{\xi_{\nu}=x_{i}+\nu h_{\xi} ; \eta_{\mu}=y_{j}+\mu h_{\nu} ; \quad \nu=0,1,2, \ldots, n p, \mu=0,1,2, \ldots, m q\right\} .
$$

It is clear that $\bigcup_{i, j} \Omega_{\left(h_{\xi}, h_{\eta}\right)}^{\left(x_{i}, y_{j}\right)}=\Omega_{\left(h_{x}, h_{y}\right)}^{(-\ell, \ell)}$. Let us write the integrals in (9) in quadratic form as follows

$$
\begin{aligned}
\int_{-\ell}^{y_{i}} u^{2}(x, \eta, t) d \eta \approx & \frac{h_{\eta}}{2} \sum_{\mu=0}^{q \cdot j} U^{2}\left(x_{i}, \eta_{\mu}, t_{k}\right), \frac{1}{2} \int_{-\ell}^{x_{i}} u^{2}\left(\xi, y_{j}, t_{k}\right) d \xi \approx \frac{h_{\xi}}{2} \sum_{\nu=0}^{p \cdot i} U^{2}\left(\xi_{\nu}, y_{j}, t_{k}\right) \\
& \int_{-\ell}^{x_{i}} \int_{-\ell}^{y_{j}} u(\xi, \eta, t) d \xi d \eta \equiv h_{\xi} h_{\eta} \sum_{\nu=0}^{i} \sum_{\mu=0}^{j} U\left(x_{\nu}, y_{\mu}, t_{k}\right) .
\end{aligned}
$$

If we take these into account (9), we obtain the following systems of finite difference equations

$$
\begin{aligned}
& W_{i, j, k+1}=W_{i, j, k}+\frac{h_{t} h_{\eta}}{2} \sum_{\mu=0}^{q \cdot j}\left(U^{2}\left(x_{i}, \eta_{\mu}, t_{k}\right)-U^{2}\left(x_{0}, \eta_{\mu}, t_{k}\right)\right) \\
&+\frac{h_{t} h_{\xi}}{2} \sum_{\nu=0}^{p \cdot i}\left(U^{2}\left(\xi_{\nu}, y_{j}, t_{k}\right)-U^{2}\left(\xi_{0}, y_{j}, t_{k}\right)\right), \\
&(i=0,1,2, \ldots, n ; j=0,1,2, \ldots, m ; k=0,1,2, \ldots) .
\end{aligned}
$$

For (12), the initial condition is as follows

$$
W_{i, j, 0}=w_{0}\left(x_{i}, y_{j}\right), \quad(i=0,1,2, \ldots, n ; j=0,1,2, \ldots, m) .
$$

Corresponding difference analogy for (9) is

$$
\begin{aligned}
V\left(x_{i}, y_{j}, t_{k+1}\right)=V\left(x_{i}, y_{j}, t_{k}\right)-\frac{h_{t}}{2} \sum_{\ell=0}^{k}\left\{h_{\eta} \sum_{\mu=1}^{q j}\left[U^{2}\left(x_{i}, \eta_{\mu}, t_{k}\right)-U^{2}\left(a, \eta_{\mu}, t_{k}\right)\right]\right. \\
\left.+h_{\xi} \sum_{\nu=1}^{p i}\left[U^{2}\left(\xi_{\nu}, y_{j}, t_{k}\right)-U^{2}\left(\xi_{\nu}, c, t_{k}\right)\right]\right\} .
\end{aligned}
$$

As above

$$
\frac{V\left(x_{i}, y_{j}, t_{k+1}\right)-V\left(x_{i-p_{1}}, y_{j}, t_{k+1}\right)}{p_{1}}+\frac{V\left(x_{i}, y_{j}, t_{k+1}\right)-V\left(x_{i}, y_{j-q_{1}}, t_{k+1}\right)}{q_{1}}
$$




$$
\begin{gathered}
=\frac{V\left(x_{i}, y_{j}, t_{k}\right)-V\left(x_{i-p_{1}}, y_{j}, t_{k}\right)}{p_{1}}+\frac{V\left(x_{i}, y_{j}, t_{k}\right)-V\left(x_{i}, y_{j-q_{1}}, t_{k}\right)}{q_{1}} \\
-\frac{h_{t}}{2} \sum_{\ell=0}^{k}\left\{\sum _ { \mu = 1 } ^ { q j } \left[\frac{h_{\eta}}{q_{1}}\left[U^{2}\left(x_{i}, \eta_{\mu}, t_{k}\right)-U^{2}\left(a, \eta_{\mu}, t_{k}\right)\right]+\frac{h_{\eta}}{p_{1}}\left[U^{2}\left(x_{i}, \eta_{\mu}, t_{k}\right)\right.\right.\right. \\
\left.\left.-U^{2}\left(x_{i-p_{1}}, \eta_{\mu}, t_{k}\right)\right]\right]+\sum_{\nu=1}^{p i}\left[\frac{h_{\xi}}{q_{1}}\left[U^{2}\left(\xi_{\nu}, y_{j}, t_{k}\right)-U^{2}\left(\xi_{\nu}, y_{j-q_{1}}, t_{k}\right)\right]\right. \\
\left.+\frac{h_{\xi}}{p_{1}}\left[U^{2}\left(\xi_{\nu}, y_{j}, t_{k}\right)-U^{2}\left(\xi_{\nu}, c, t_{k}\right)\right]\right]-\frac{h_{\eta}}{q_{1}} \sum_{\mu=1}^{q\left(j-q_{1}\right)}\left[U^{2}\left(x_{i}, \eta_{\mu}, t_{k}\right)-U^{2}\left(\xi_{\nu}, c, t_{k}\right)\right] \\
\left.-\frac{h_{\xi}}{p_{1}} \sum_{\nu=1}^{p\left(i-p_{1}\right)}\left[U^{2}\left(\xi_{\nu}, y_{j}, t_{k}\right)-U^{2}\left(\xi_{\nu}, c, t_{k}\right)\right]\right\} \leq \frac{E_{1}}{t}
\end{gathered}
$$

where $E_{1}$ is a constant. So we have obtained entropy solution of the Cauchy problem for Burgers equation.

From (12) we obtain the following

$$
U_{i, j, k+1}=h_{x} h_{y} \sum_{\nu=1}^{i} \sum_{\mu=1}^{j} W\left(x_{\nu}, y_{\mu}, t_{k+1}\right),(i=0,1, \ldots, n ; j=0,1, \ldots, m ; k=0,1, \ldots) .
$$

In addition, by using equation (9), finite difference schemes on higher orders with respect to $t$ (such as Runge-Kutta method) can be used.

\section{Numerical experiments}

Two sets of computer experiments are performed using the algorithm proposed above. Such as grid steps with respect to spatial and time variables and the size of the grid is $[0, T] \times[-4.0,4.0], h_{\xi}=\frac{h_{x}}{p}, h_{\eta}=\frac{h_{y}}{q}$, $h_{x}=\frac{b-a}{h}, h_{y}=\frac{d-c}{m}, p=q=10, n=m=533, t_{k}=0.005$.

In the first of the series of experiments, as seen in Figures 2 and 3, it is assumed that the jump strip on the initial condition is in each quadrant of $x y$ plane. The results obtained for the cases $u_{1}=1, u_{2}=0$ and $u_{1}=0$, $u_{2}=1$ are shown in Figure 2 and 3, respectively. Solutions of the auxiliary problem (12), (13) are shown in the first column of Figure 2 and Figure 3. By using (14) the solution of the auxiliary problem is obtained and the second column shows the solutions of the main problem (1), (2). In the third column, contours of shock and rarefaction waves are illustrated.

As seen in Figure 2, in the cases of the initial profile at $(1,0,0,0)$ and $(0,0,1,0)$ it is observed that two rarefaction and two shock waves occur. In the other cases, at $(0,1,0,0)$ and $(0,0,0,1)$, one shock and one rarefaction wave are detected (Figure 3). Comparing the results obtained with the solutions found in [15] with same data, the importance of the proposed auxiliary problem emerges.

In the second series of experiments, as seen in figures, it is assumed that the jump-fan is in each quadrant of the $x y$ plane. In these cases, as shown in Figure 4, one shock and one rarefaction wave occur in all cases.

In Figure 5, we assume that the initial data has $u_{1}=0, u_{2}=1$ and the dynamics of the wave propagation at $T=1$ are shown. The results obtained for the cases $u_{1}=1, u_{2}=0$ and $u_{1}=0, u_{2}=1$ are shown in Figure 4 and 5 , respectively. As seen from the figures one shock and one rarefaction wave always occur on the quadrants.

The solutions we obtained show that the proposed numerical algorithm is highly sensitive and describes all of the physical properties of the phenomenon correctly. 
Grid method for ...

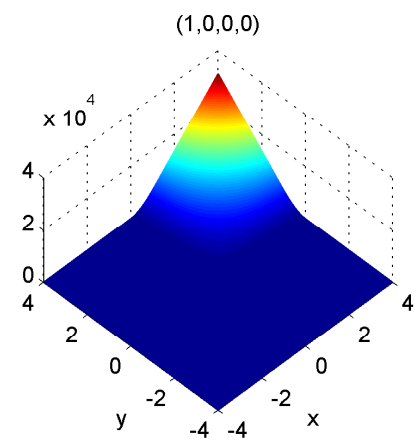

(a)

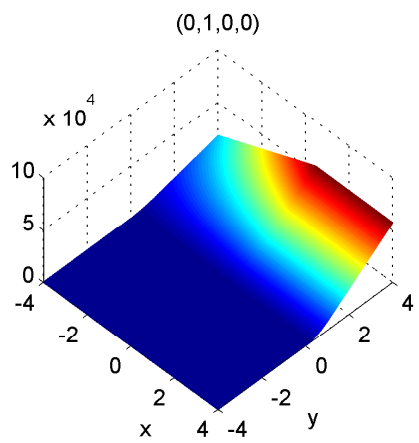

(d)

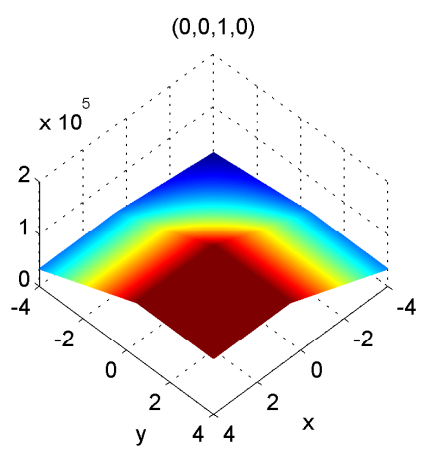

(g)

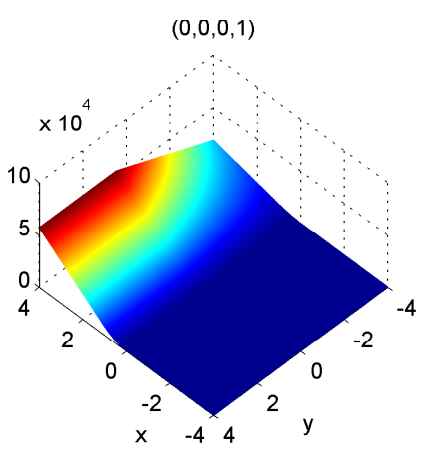

(j)

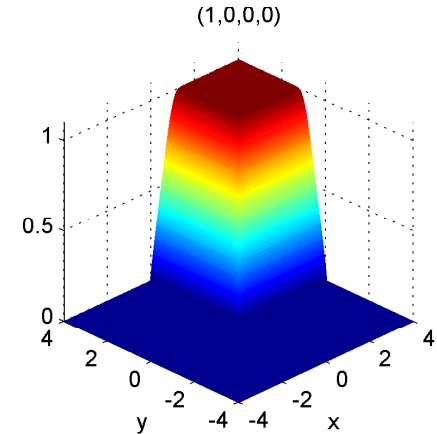

(b)

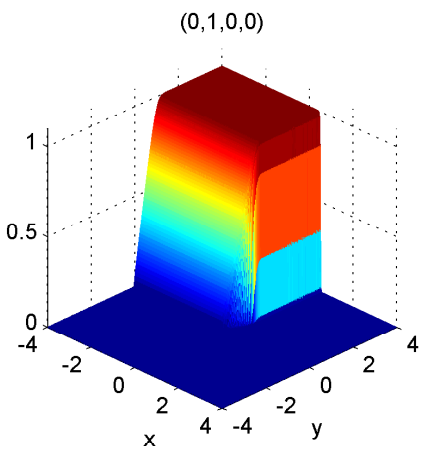

(e)

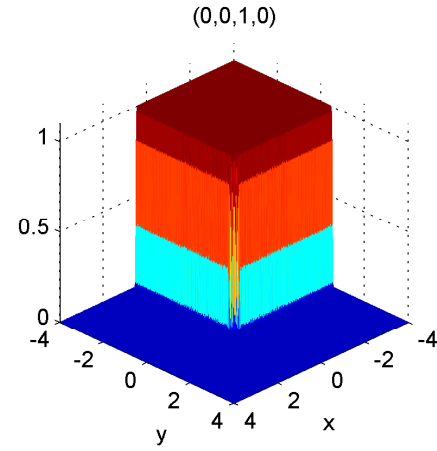

(h)

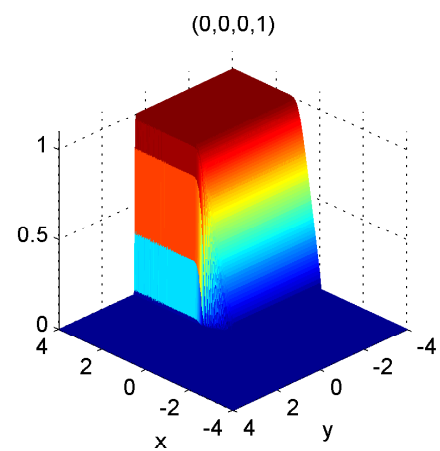

(k)

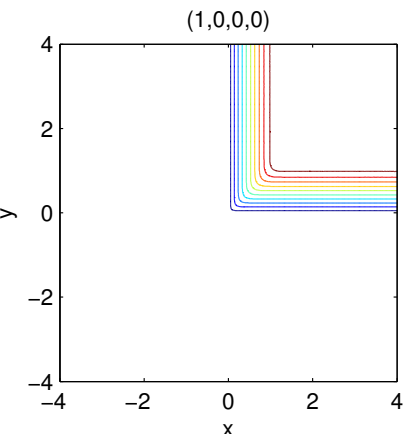

(c)

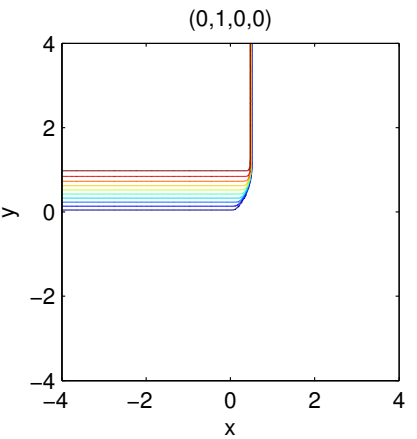

(f)

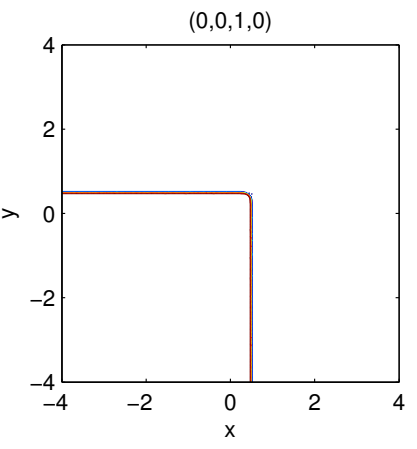

(i)

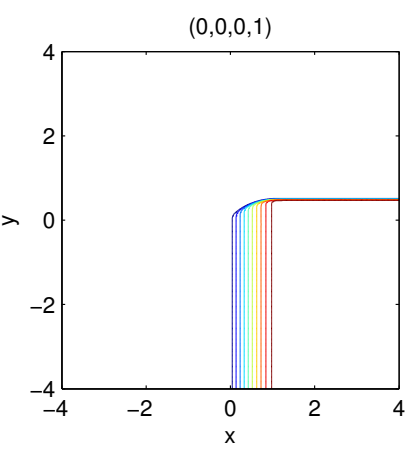

(1)

Figure 2. (a)-(c): $\varphi_{1}=0, \varphi_{2}=\frac{\pi}{2} ;(\mathrm{d})-(\mathrm{f}): \varphi_{1}=\frac{\pi}{2}, \varphi_{2}=\pi ;(\mathrm{g})-(\mathrm{i}): \varphi_{1}=\pi, \varphi_{2}=\frac{3 \pi}{2} ;(\mathrm{j})-(\mathrm{l}): \varphi_{1}=\frac{3 \pi}{2}, \varphi_{2}=2 \pi$ 


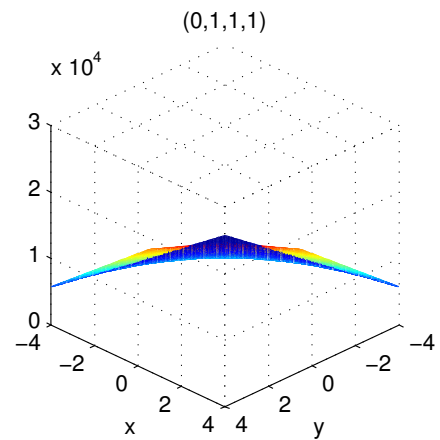

(a)

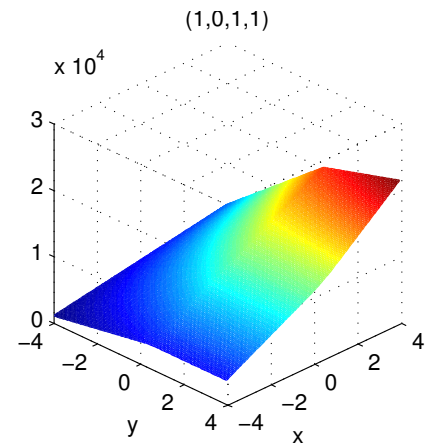

(d)

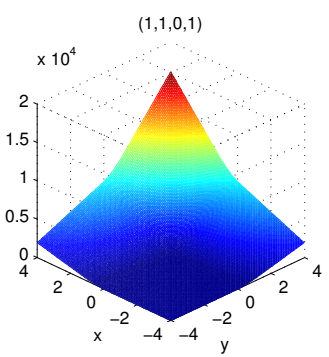

(g)

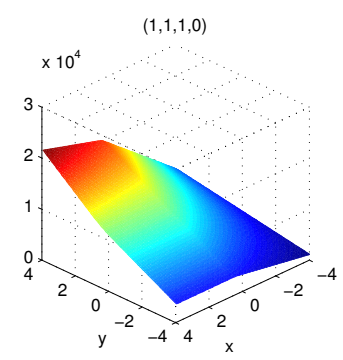

(j)

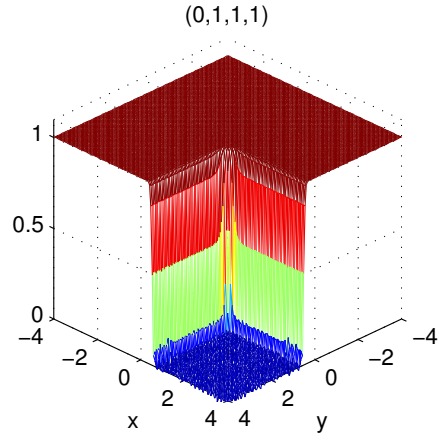

(b)

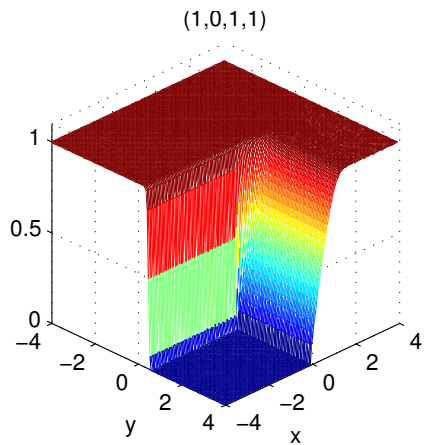

(e)

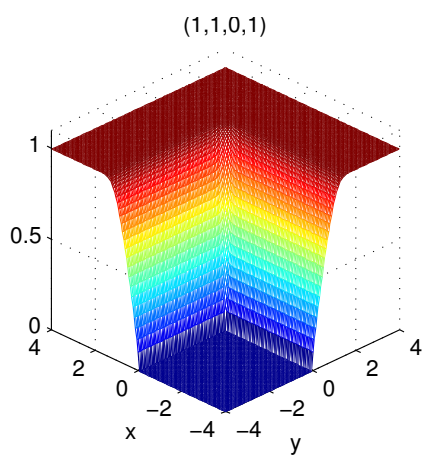

(h)

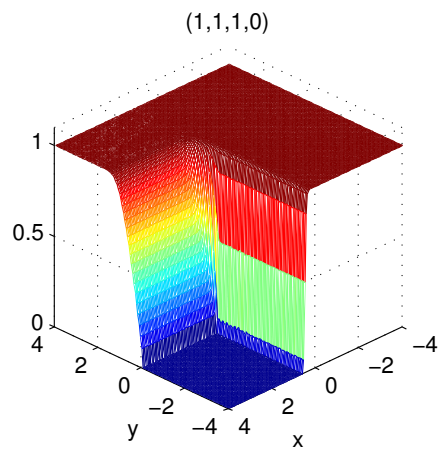

(k)

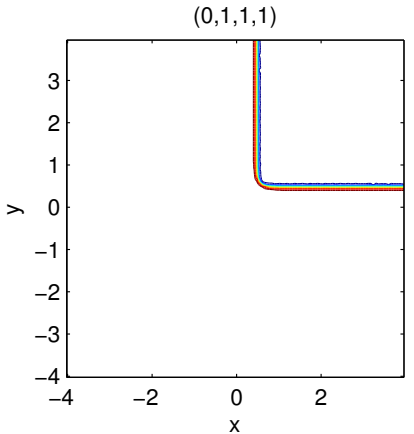

(c)

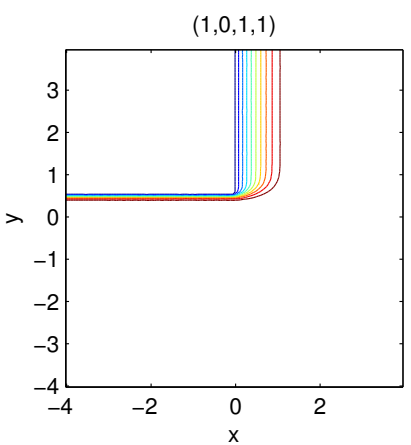

(f)

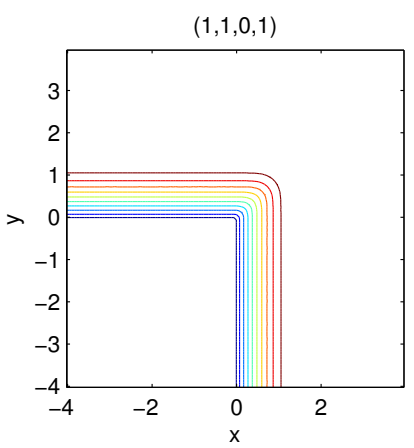

(i)

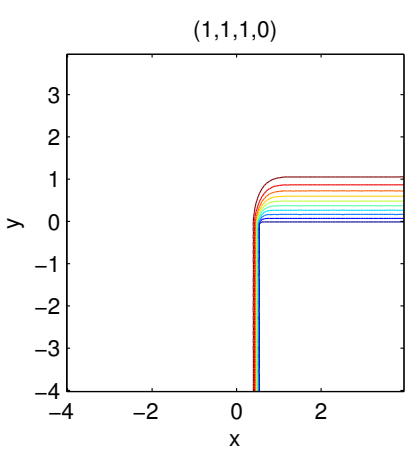

(l)

Figure 3. (a)-(c): $\varphi_{1}=0, \varphi_{2}=\frac{\pi}{2} ;(\mathrm{d})-(\mathrm{f}): \varphi_{1}=\frac{\pi}{2}, \varphi_{2}=\pi ;(\mathrm{g})-(\mathrm{i}): \varphi_{1}=\pi, \varphi_{2}=\frac{3 \pi}{2} ;(\mathrm{j})-(\mathrm{l}): \varphi_{1}=\frac{3 \pi}{2}, \varphi_{2}=2 \pi$ 


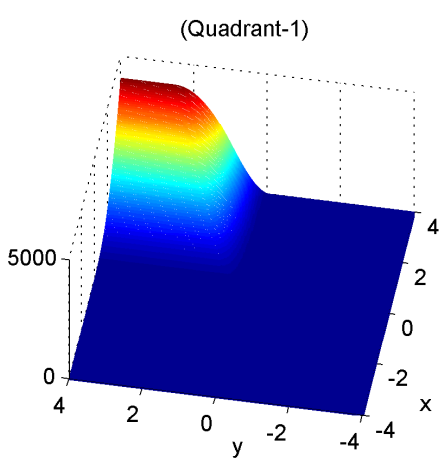

(a)

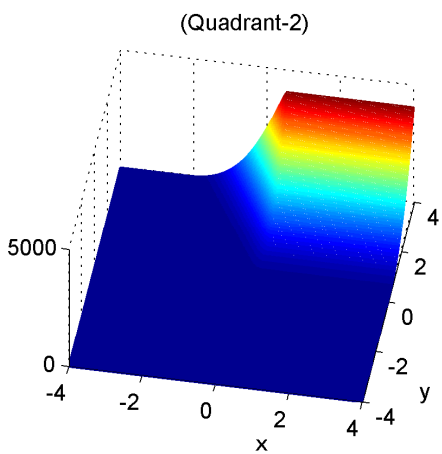

(d)

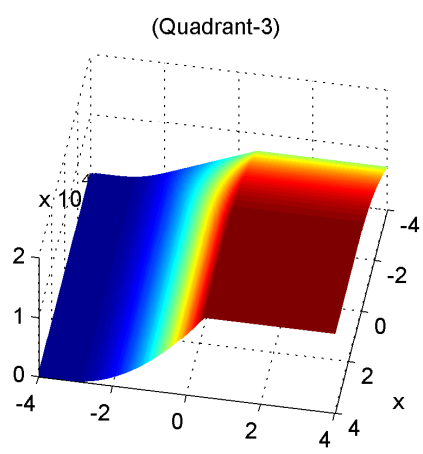

(g)

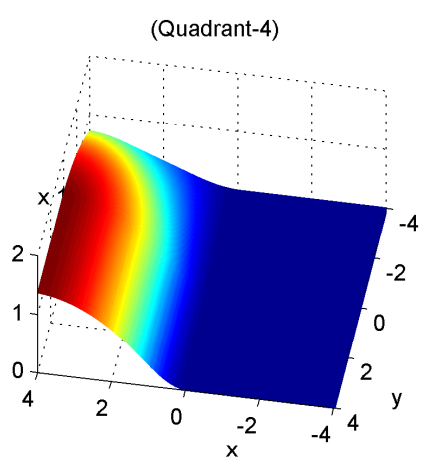

(j)

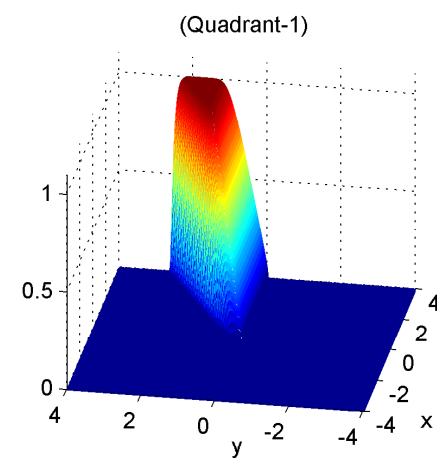

(b)

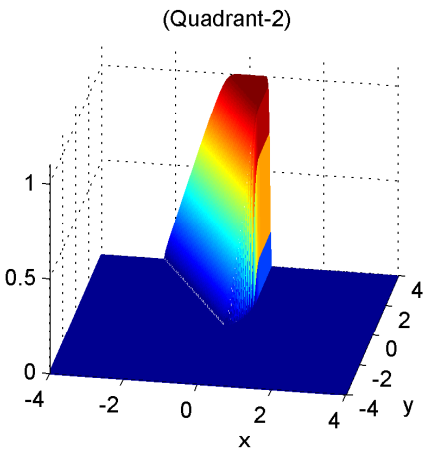

(e)

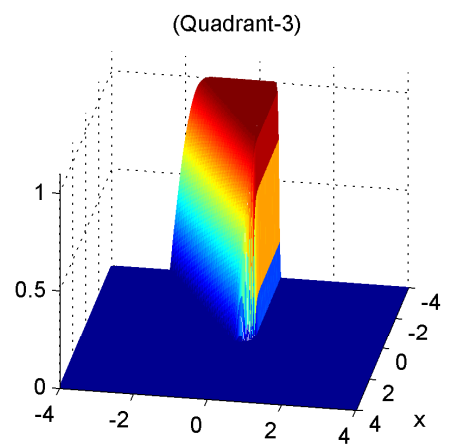

(h)

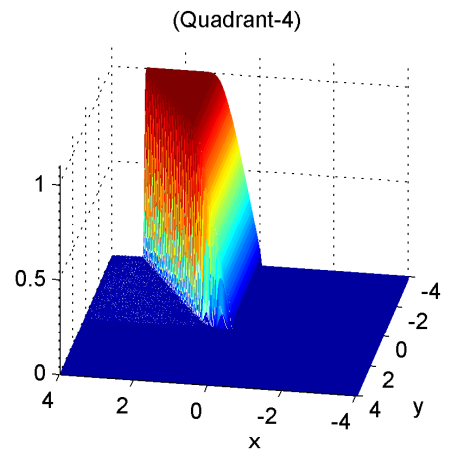

(k)

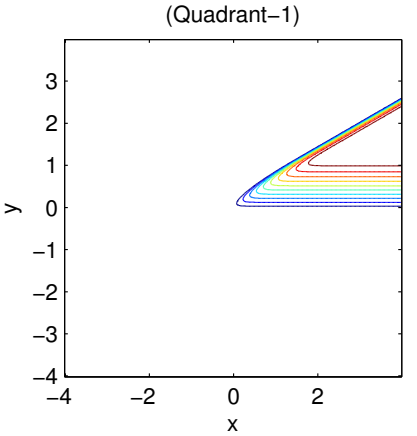

(c)

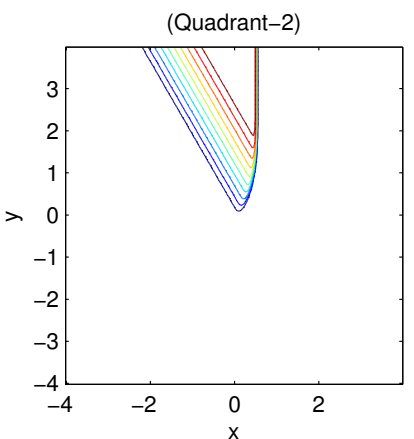

(f)

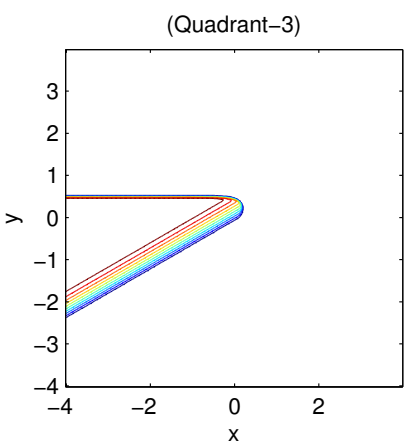

(i)

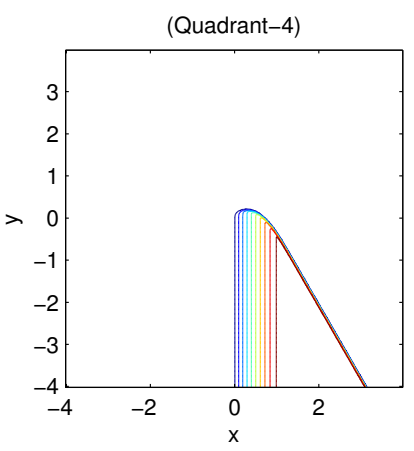

(l)

Figure 4. (a)-(c): $\varphi_{1}=0, \varphi_{2}=\frac{\pi}{6} ;(\mathrm{d})-(\mathrm{f}): \varphi_{1}=\frac{\pi}{2}, \varphi_{2}=\frac{2 \pi}{3} ;(\mathrm{g})-(\mathrm{i}): \varphi_{1}=\pi, \varphi_{2}=\frac{5 \pi}{6} ;(\mathrm{j})-(\mathrm{l}): \varphi_{1}=\frac{3 \pi}{2}$, $\varphi_{2}=\frac{7 \pi}{6}$ 


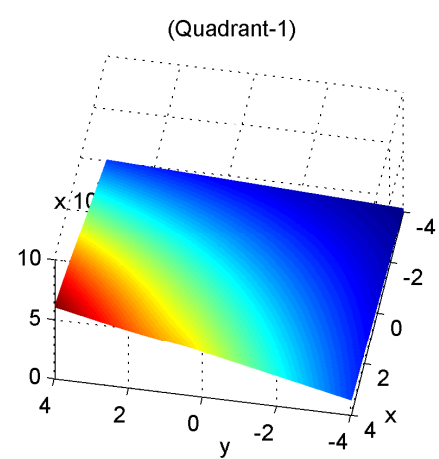

(a)

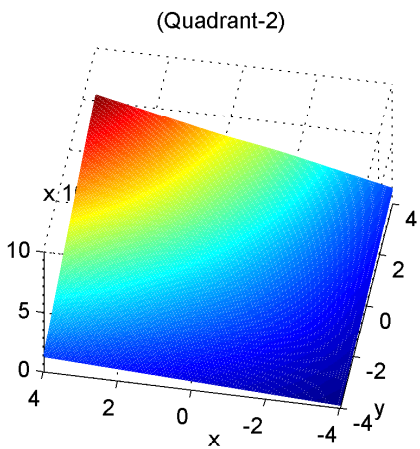

(d)

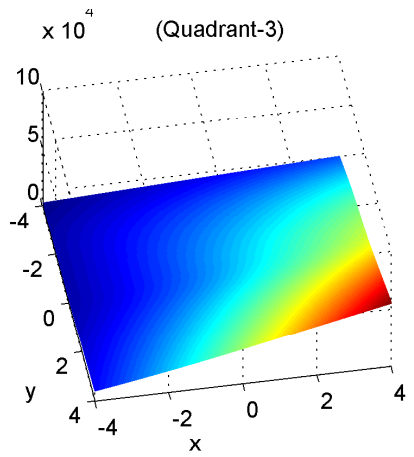

(g)

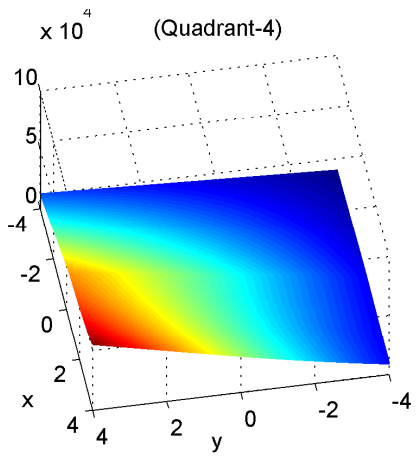

(j)

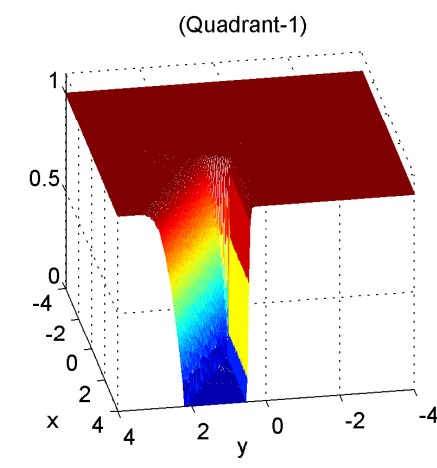

(b)

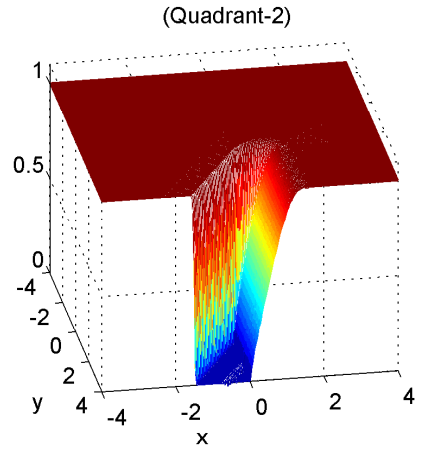

(e)

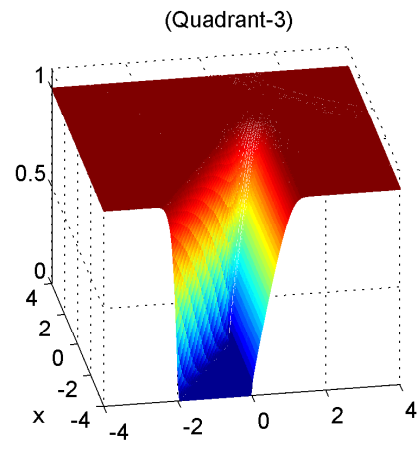

(h)

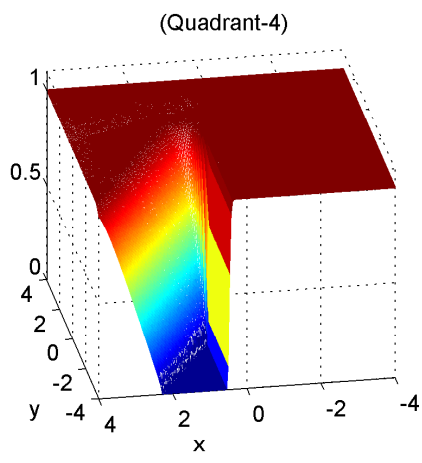

(k)

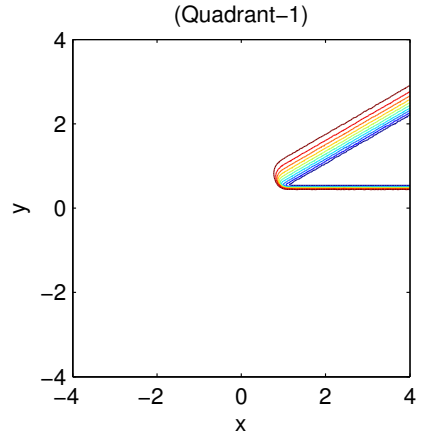

(c)

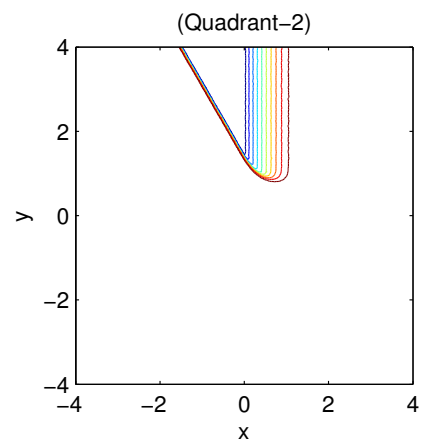

(f)

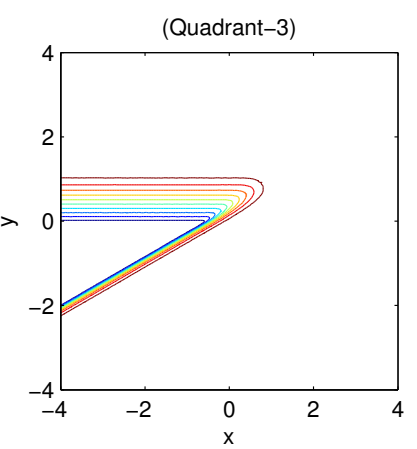

(i)

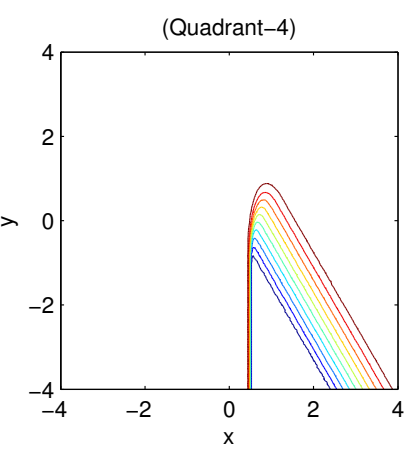

(1)

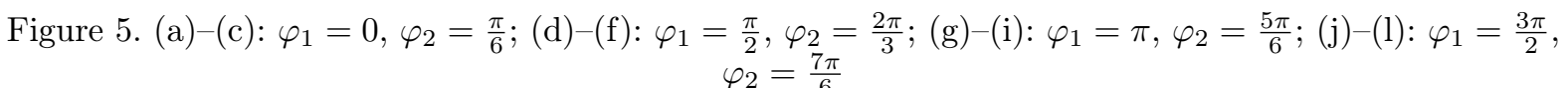




\section{Conclusion}

In this study an original method for the numerical solution of the initial value problem for two-dimensional conservation law with two-piecewise constant discontinuous initial condition that accurately describes the all physical properties of the problem is proposed.

In addition to this, the auxiliary problem has provided the entropy condition, which provides the uniqueness of the solution. In establishing efficient algorithms for the numerical solution of the two-dimensional Riemann type problem the method incorporates an auxiliary problem that is equivalent to the original problem, and yet has advantages over it.

\section{References}

1 Conway E. Global Solution of the Cauchy Problem for Quasilinear First Order Equation in Several Variables / E. Conway, J. Smoller // Comm. Pure Appl. Math. - 1996. - XIX. — P. 95-105.

2 Gelfand I.M. Some Problems in the Theory of Quasilinear Equations / I.M. Gelfand // Usp Math. Nauk. - 1959. - 14. - P. 87-158. / Amer. Math. Soc Transl. - 1963. - 29. - P. 295-381.

3 Kruzkov S.N. First Order Quasilinear Equation in Several Independent Variables / S.N. Kruzkov // Math. Sbornik. - 1970. - 81. - P. 217-243.

4 Volpert A.I. The spaces BV and quasilinear equations / A.I. Volpert // Math. USSR-Sbornik. - 1967. 2. - P. 225-267.

5 Hormander L. Lectures on Nonlinear Hyperbolic Differential Equations / L. Hormander. - New-York: Springer-Verlag, 1997.

6 Lax P.D. Hyperbolic Systems of Conservation Laws and the Mathematical Theory of Shock Waves / P.D. Lax // Conf. Board Math. Sci. Regional Conf. Series in Appl. Math. 11, SIAM, Society for Industrial and Applied Mathematics, Philadelphia. - 1972. - 11.

7 Oleinik O.A. Discontinuous Solitions of Nonlinear Differential Equations / O.A. Oleinik // Usp.Math. Nauk. - 1957. - 12. - No. 3. - P. 3-73.

8 Smoller J.A. Shock Wave and Reaction Diffusion Equations / J.A. Smoller. - New-York: Springer-Verlag, 1983.

9 Guckenheimer J. Shocks and Rarefactions in Two Space Dimensions / J. Guckenheimer // Arch. Rational Mech. Anal. - 1975. - 59. - No. 3. - P. 281-291.

10 Chen G-Q. Structure of Riemann Solutions for 2-Dimensional Scalar Conservation Laws / G-Q. Chen, D.Li, D.Tan // Journal of Differential Equations. - 1996. - 127. - No. 1. - P. 124-147.

11 Lindquist W.B. The Scalar Riemann Problem in Two Spatial Dimensions: Piecewise Smoothness of Solutions and Its Breakdown / W.B. Lindquist // SIAM J. Math. Anal. - 1989. - 17. — No. 5. - P. $1178-1197$.

12 Lindquist W.B. Construction of Solutions for Two-Dimensional Riemann Problems / W.B. Lindquist // Comput. Math. Appl. Part A. - 1986. - 12. - No. 4-5. - P. 615-630.

13 Malek J. Weak and Measure-Valued Solutions to Evolutionary PDEs / J. Malek, J. Necas, M. Rokyta, M. Ruzicka. - London: Chapman-Hall, 1996.

14 Sheng W-C. Two-Dimensional Riemann Problem for Scalar Conservation Laws / W-C. Sheng // Journal of Differential Equations. - 2002. - 183. - P. 239-261.

15 Wagner D.H. The Riemann Problem in Two Space Dimensions for a Single Conservation Law / D.H. Wagner // SIAM J. Math. Anal. - 1983. - 14. - P. 534-559.

16 Zhang P. Generalized Characteristic Analysis and Guckenheimer Structure / T. Zhang, Y. Zheng // Journal of Differential Equations. - 1999. - 152. - P. 409-430.

17 Zhang T. Two-Dimensional Riemann Problem for a Single Conservation Law / T. Zhang, Y. Zheng // Transactions of the American Mathematical Society. - 1989. - 312. - No. 2. - P. 589-619

18 Zheng Y. Systems of Conservation Laws Two-Dimensional Riemann Problems / Y. Zheng // Birkhauser, in the Series of Progress in Nonlinear Differential Equations, 2001.

19 Ben-Artzi M. Wave Interactions and Numerical Approximation for Two-Dimensional Scalar Conservation Laws / M. Ben-Artzi, J. Falcovitz, J-Q. Li // Computational Fluid Dynamics Journal. — 2006. - 14. — P. 401-418. 
20 Levy D. A Third Order Central WENO Scheme for 2D Conservation Laws / D. Levy, G. Puppo, G. Russo // Applied Numerical Mathematics. - 2000. - 33. - P. 415-421.

21 Liska R. Composite- Schemes for Conservation Law / R. Liska, B. Wendroff // SIAM, J. Numer. Anal. - 1998. - 35. - No. 6. - P. 2250-2271.

22 Rasulov M.A. Süreksiz Fonksiyonlar Sınıfında Korunum Kuralları. Istanbul: Seçkin Yayıncılık, 2011.

23 Yoon D. Two-Dimensional Riemann Problem for Burgers Equation / D. Yoon, W. Hwang // Bull. Korean Math. Soc. - 2008. - 45. - No. 1. - P. 191-205.

24 Rasulov M.A. Identification of the Saturation Jump in the Process of Oil Displacement by Water in a 2D Domain / M.A. Rasulov // Dokl. RAN. - 1991. - 319. - No. 4. - P. 943-947.

25 Rasulov M.A. Finite Differences Method for a Two-Dimensional Nonlinear Hyperbolic Equations in a Class of Discontinuous Functions / M.A. Rasulov, E. Coskun, B. Sinsoysal // App. Mathematics and Computation. - 2003. - 140. - No. 1. - P. 279-295.

26 Abasov M.T. On a Method of Solving the Cauchy Problem for a First Order Nonlinear Equation of Hyperbolic Type with a Smooth Initial Condition / M.T. Abasov, M.A. Rasulov, T.M. Ibrahimov, T.A. Ragimova // Soviet Math. Dok. - 1991. - 43. - No. 1. - P. 150-153.

\author{
Б. Синсойсал ${ }^{1}$, М. Расулов ${ }^{2}$, О. Енер ${ }^{3}$ \\ 1 Догус университеті, Стамбул, ТҮркия; \\ 2 Әзірбайжан Ұлттық, вылым академиясының, Мұнай және газ институты, Баку, Әзірбайжан; \\ ${ }^{3}$ Бейкент университеті, Стамбул, Түркия
}

\title{
Бастапқы күйде екі үзілісі бар Риман типті екі өлшемді есепті шешудің тор әдісі
}

\begin{abstract}
Зерттеудің мақсаты - бастапқы профилі бар бір еркін үзілісті сақталу заңының екі өлшемді теңдеуі үшін Коши есебінің сандық шешімін алу. Ол үшін негізгі есептің әлсіз шешімін алуда сезімтал әдісті құруға мүмкіндік беретін арнайы көмекші есеп құрылады. Ұсынылған көмекші есеп, сонымен қатар, көмекші есепті шешімнің жалғыз болуына кепілдік беретін энтропияның шарттарын табуға мүмкіндік береді. Сандық шешімді дәл шешіммен салыстыру үшін алдымен есептің теориялық құрылымы, содан кейін соққы толқындары мен сирету толқындарының өзара әрекеттесуі зерттелген.
\end{abstract}

Kiлm сөздер: бейсызықты скалярлы 2D сақтау заңы, Риманның есептері, үзілісті функциялар класындағы ақырлы-айырымды схема, екі өлшемді есептер.

\author{
Б. Синсойсал ${ }^{1}$, М. Расулов ${ }^{2}$, О. Енер ${ }^{3}$ \\ ${ }^{1}$ Университет Догус, Стамбул, Туриия; \\ ${ }^{2}$ Институт нефти и газа Национальной академии наук Азербайджана, Баку, Азербайджан; \\ ${ }^{3}$ Университет Бейкент, Стамбул, Туриия
}

\section{Сеточный метод решения двумерной задачи типа Римана с двумя разрывами, имеющими начальное состояние}

Цель данного исследования - получение численного решения задачи Коши для двумерного уравнения закона сохранения с одним произвольным разрывом, имеющим начальный профиль. Для этого разработана специальная вспомогательная задача, позволяющая построить чувствительный метод для получения слабого решения основной задачи. Предлагаемая вспомогательная задача также позволяет найти условие энтропии, гарантирующее единственность решения вспомогательной задачи. Для сравнения численного решения с точным сначала исследована теоретическая структура рассматриваемой задачи, а затем изучено взаимодействие ударных волн и волн разрежения.

Ключевые слова: нелинейный скалярный 2D закон сохранения, задача Римана, конечно-разностная схема в классе разрывных функций, двумерное уравнение. 


\section{References}

1 Conway, E., \& Smoller, J. (1966). Global solution of the Cauchy problem for quasilinear first order equation in several variables. Comm. Pure Appl. Math., XIX, 95-105.

2 Gelfand, I.M. (1963). Some problems in the theory of quasilinear equations. Translation Amer. Math. Soc Transl., 29, 295-381.

3 Kruzkov, S.N. (1970). First order quasilinear equation in several independent variables. Math. Sbornik, $81,217-243$.

4 Volpert, A.I. (1967). The spaces BV and quasilinear equations. Math. USSR-Sbornik, 2, $225-267$.

5 Hormander, L. (1997). Lectures on Nonlinear Hyperbolic Differential Equations. New-York: SpringerVerlag.

6 Lax, P.D. (1987). Hyperbolic Systems of Conservation Laws and the Mathematical Theory of Shock Waves. Conf. Board Math. Sci. Regional Conf. Series in Appl. Math. 11, SIAM, Society for Industrial and Applied Mathematics, Philadelphia.

7 Oleinik, O.A. (1957). Discontinuous solitions of nonlinear differential equations. Usp.Math. Nauk, 12(3), 3-73.

8 Smoller, J.A. (1983). Shock Wave and Reaction Diffusion Equations. New-York: Springer-Verlag.

9 Guckenheimer, J. (1975). Shocks and rarefactions in two space dimensions. Arch. Rational Mech. Anal., $59(3), 281-291$.

10 Chen, G-Q., Li, D., \& Tan, D. (1996). Structure of Riemann solutions for 2-dimensional scalar conservation laws. Journal of Differential Equations, 1271(1), 124-147.

11 Lindquist, W.B. (1986). The scalar Riemann problem in two spatial dimensions: piecewise smoothness of solutions and its breakdown. SIAM J. Math. Anal., 17(5), 1178-1197.

12 Lindquist, W.B. (1986). Construction of solutions for two-dimensional Riemann problems. Comput. Math. Appl. Part A, 12(4-5), 615-630.

13 Malek, J., Necas, J., Rokyta, M., \& Ruzicka, M. (1996). Weak and Measure-Valued Solutions to Evolutionary PDEs. London: Chapman-Hall.

14 Sheng, W.C. (2002). Two-dimensional Riemann problem for scalar conservation laws. Journal of Differential Equations, 183, 239-261.

15 Wagner, D.H. (1983). The Riemann problem in two space dimensions for a single conservation law. SIAM J. Math. Anal., 14, 534-559.

16 Zhang, P., \& Zhang, T. (1999). Generalized characteristic analysis and Guckenheimer structure. Journal of Differential Equations, 152, 409-430.

17 Zhang, T., \& Zheng, Y. (1989). Two-Dimensional Riemann Problem for a Single Conservation Law. Transactions of the American Mathematical Society, 312(2), 589-619.

18 Zheng, Y. (2001). Systems of Conservation Laws Two-Dimensional Riemann Problems. Birkhauser, in the Series of Progress in Nonlinear Differential Equations.

19 Ben-Artzi, M., Falcovitz, J., \& Li, J-Q. (2006). Wave interactions and numerical approximation for twodimensional scalar conservation laws. Computational Fluid Dynamics Journal, 14, 401-418.

20 Levy, D., Puppo, G., \& Russo, G. (2000). A third order central WENO scheme for 2D conservation laws. Applied Numerical Mathematics, 33, 415-421.

21 Liska, R., \& Wendroff, B. (1998). Composite schemes for conservation law. SIAM J. Math. Anal., 35(6), 2250-2271.

22 Rasulov, M.A. (2011). Sureksiz fonksiyonlar sinifinda korunum kurallari /Conservation rules in the class of discontinuous functions]. Istanbul: Publishing house Seckin Yayinevi [in Turkish].

23 Yoon, D.,\& Hwang, W. (2008). Two-dimensional Riemann problem for Burgers equation. Bull. Korean Math. Soc., 45(1), 191-205.

24 Rasulov, M.A. (1991). Identification of the saturation jump in the process of oil displacement by water in a 2D domain. Dokl. RAN, 319(4), 943-947.

25 Rasulov, M.A, Coskun, E., \& Sinsoysal, B. (2003). Finite differences method for a two-dimensional nonlinear hyperbolic equations in a class of discontinuous functions. App. Mathematics and Computation, 140(1), 279-295. 
26 Abasov, M.T., Rasulov, M.A., Ibrahimov, T.M., \& Ragimova, T.A. (1991). On a method of solving the Cauchy problem for a first order nonlinear equation of hyperbolic type with a smooth initial condition. Soviet Math. Dok., 43(1), 150-153. 